\title{
Discovery of a Novel Member of the Histamine Receptor Family
}

\author{
TUAN NGUYEN, DAVID A. SHAPIRO, SUSAN R. GEORGE, VINCENT SETOLA, DENNIS K. LEE, REGINA CHENG, \\ LAURA RAUSER, SAMUEL P. LEE, KEVIN R. LYNCH, BRYAN L. ROTH, and BRIAN F. O'DOWD \\ The Centre for Addiction and Mental Health, Toronto, Ontario, Canada (T.N., S.R.G., R.C., B.F.O.); Departments of Pharmacology \\ (S.R.G., D.K.L., S.P.L., B.F.O.) and Medicine (S.R.G.), University of Toronto, Toronto, Ontario, Canada; Department of Biochemistry \\ (D.A.S., V.S., B.L.R.) and National Institute of Mental Health Psychoactive Drug Screening Program (L.R., B.L.R.), Case Western Reserve \\ University Medical School, Cleveland, Ohio; and Department of Pharmacology, University of Virginia Health Sciences Center, Charlottesville, \\ Virginia (K.R.L).
}

Received October 4, 2000; accepted January 5, 2001

This paper is available online at http://molpharm.aspetjournals.org

\section{ABSTRACT}

We report the discovery, tissue distribution and pharmacological characterization of a novel receptor, which we have named $\mathrm{H} 4$. Like the three histamine receptors reported previously $(\mathrm{H} 1$, $\mathrm{H} 2$, and $\mathrm{H} 3$ ), the $\mathrm{H} 4$ receptor is a $\mathrm{G}$ protein-coupled receptor and is most closely related to the $\mathrm{H} 3$ receptor, sharing $58 \%$ identity in the transmembrane regions. The gene encoding the $\mathrm{H} 4$ receptor was discovered initially in a search of the GenBank databases as sequence fragments retrieved in a partially sequenced human genomic contig mapped to chromosome 18. These sequences were used to retrieve a partial cDNA clone and, in combination with genomic fragments, were used to determine the full-length open reading frame of 390 amino acids. Northern analysis revealed a 3.0-kb transcript in rat testis and intestine. Radioligand binding studies indicated that the $\mathrm{H} 4$ receptor has a unique pharmacology and binds $\left[{ }^{3} \mathrm{H}\right]$ histamine $\left(K_{\mathrm{d}}=44 \mathrm{nM}\right)$ and $\left[{ }^{3} \mathrm{H}\right]$ pyrilamine $\left(K_{\mathrm{d}}=32 \mathrm{nM}\right)$ and several psychoactive compounds (amitriptyline, chlorpromazine, cyproheptadine, mianserin) with moderate affinity $\left(K_{\mathrm{i}}\right.$ range of $\left.33-750 \mathrm{nM}\right)$. Additionally, histamine induced a rapid internalization of HAtagged $\mathrm{H} 4$ receptors in transfected human embryonic kidney 293 cells.
Histamine is a monoamine neurotransmitter thus far known to activate three $G$ protein-coupled receptors (GPCRs), the H1, H2, and H3 receptors (Hill et al., 1997). Although molecular cloning has made possible the identification, isolation, and characterization of the majority of known GPCRs, the histamine receptor subtypes have proven more difficult to identify. The first two histamine receptor genes cloned were H1 (Yamashita et al., 1991) and H2 (Gantz et al., 1991). The identification of the H3 receptor came nearly a decade later (Lovenberg et al., 1999). Collectively, the $\mathrm{H} 1, \mathrm{H} 2$, and $\mathrm{H} 3$ receptors share less than 35\% identity with one another and each has greater sequence identities with other aminergic receptors. Thus, the histamine receptor gene family is significantly divergent and may have evolved

This research was funded by the Canadian Institutes of Health Research (B.F.O. and S.R.G.), the National Institute on Drug Abuse (B.F.O. and S.R.G.), and in part by K02-MH01366 and N01-80005 to B.L.R.

T.N. and D.A.S. contributed equally to this work. from different ancestral genes (Leurs et al., 2000). In addition, there is evidence that multiple subtypes of the $\mathrm{H} 3$ receptor may exist. Pharmacological studies performed on membranes extracted from rat brain tissue revealed two classes of H3 binding sites (West et al., 1990; Leurs et al., 1996). However, efforts to clone a second H3 receptor subtype in the brain have thus far been unsuccessful.

Through molecular cloning techniques, we have identified numerous novel GPCRs, including many subtypes not suspected to exist on the basis of pharmacology. Over the past decade, our cloning efforts have identified a number of GPCR genes, including genes encoding such receptors as the cysteinyl leukotriene CysLT2 (Heise et al., 2000), galanin GalR2 and GalR3 (Kolakowski et al., 1998), thyrotropin-releasing hormone TRH-R2 (O'Dowd et al., 2000), uridine nucleotide receptor UNR (Nguyen et al., 1995), as well as a large cohort of orphan GPCRs for which the endogenous ligands remain to be elucidated (Marchese et al., 1999; Lee et al., 2001). In a 
scan of the GenBank high-throughput genomic sequence (HTGS) database, we identified a small DNA fragment that had greatest homology to the known histamine receptor genes. Here we report the discovery, tissue distribution, and pharmacological characterization of human DNA encoding a receptor, H4. H4 receptor mRNA had discrete and limited expression in rat testis and intestine. Although the $\mathrm{H} 4$ receptor was most closely related to the $\mathrm{H} 3$ receptor [58\% identity in the transmembrane (TM) regions], it seemed to possess a unique pharmacology, with highest affinity for psychoactive drugs (amitriptyline, chlorpromazine) with a tricyclic structure.

\section{Materials and Methods}

Database Searching. A customized search was used to query the GenBank HTGS database of high-throughput genomic sequences maintained by the National Center for Biotechnology Information (NCBI) with the sequences of various GPCRs, using the FAST_PAN program (Retief et al., 1999).

Screening and Construction of the H4 Receptor Gene. Partial sequences encoding the $\mathrm{H} 4$ receptor were used to design primers to PCR-amplify H4-encoding fragments from human genomic DNA. A fragment encoding the start methionine to TM2 was amplified using primers P1 (5'-ATGCCAGATACTAATAGCACAATC-3') and P2 (5'-CACAAAGAAGTCAGAGATGG-3') and another fragment encoding from TM5 to TM6 using primers P3 (5'-TGGTACATCCTTGCCATC-3') and P4 (5'-TATGGAGCCCAGCAAACAG-3'). PCR products were extracted with phenol/chloroform, precipitated with ethanol, and electrophoresed on a low-melting agarose gel. DNA in the expected size range were excised from the gel, ligated into the EcoRV site of the pBluescript vector (Stratagene, La Jolla, CA), and then the sequence was determined. $\mathrm{H} 4$ receptor-encoding fragments were used to screen human and rat genomic libraries (CLONTECH, Palo Alto, CA) and a human testis cDNA library (CLONTECH), as described previously (Marchese et al., 1994). Isolated phages from the human and rat genomic libraries were purified and subcloned, and the sequence was determined as described previously (Marchese et al., 1994). Isolated phages from the human cDNA library were subjected to PCR amplification using primers specific for regions flanking the insert of the $\lambda$ gt10 library vector, subcloned, and sequenced.

A DNA fragment encoding the full-length human $\mathrm{H} 4$ receptor was amplified by PCR in three stages using isolated human genomic and cDNA library phage as templates. In stage 1, three overlapping fragments (A, B, and C), together encoding the full-length $\mathrm{H} 4$ receptor, were PCR-amplified as follows. Fragment A was obtained using primers P5 (5'-CATCATTTGATGTGATGCCA- $\left.3^{\prime}\right)$ and P6 (5'-CAAAGGAATGGAGATCACACCCACAAAGAAGTCAGA-3') from an isolated genomic library phage obtained with the Met-TM2 encoding DNA probe. Fragment B was obtained using primers P7 (5'-GTGATCTCCATTCCTTTG-3') and P8 (5'-TCCAATAAATATTCAT-3') from an isolated testis cDNA library phage. Fragment $\mathrm{C}$ was obtained using primers P9 (5'-TGGTACATCCTTGCCATC-3') and P10 (5'-GAGGTGAGAAAATTGTC-3') from an isolated genomic library phage obtained with the TM5-6 encoding DNA probe. In stage 2, fragments $\mathrm{B}$ and $\mathrm{C}$ were joined by PCR using primers $\mathrm{P} 7$ and P10. In stage 3, fragments $\mathrm{A}$ and $\mathrm{B} / \mathrm{C}$ were joined together using primer P5 and P10 to obtain a fragment with a length of $\sim 1200$ base pairs encoding the full-length $\mathrm{H} 4$ receptor. DNA encoding a hemagglutinin (HA) epitope tag (YPYDVPDYA) was inserted after the start methionine codon using PCR mutagenesis. This DNA was ligated into the EcoRV site of the mammalian expression vector pcDNA3 (Invitrogen, Carlsbad, CA) and its sequence was determined.

Northern Expression Analyses. mRNA from various human and rat tissues were extracted as described previously (Marchese et al., 1994). Briefly, poly(A) ${ }^{+}$RNA was isolated using oligo(dT) cellulose spin columns (Pharmacia, Uppsala, Sweden), denatured and size fractionated on a $1 \%$ formaldehyde agarose gel, transferred onto nylon membrane, and immobilized by UV irradiation. The blots were hybridized with ${ }^{32} \mathrm{P}$-labeled DNA fragments encoding the human and rat $\mathrm{H} 4$ receptor, washed with $2 \times$ standard saline/phosphate/ EDTA and $0.1 \%$ SDS at $50^{\circ} \mathrm{C}$ for $20 \mathrm{~min}$ and with $0.1 \times$ standard saline/phosphate/EDTA and $0.1 \% \mathrm{SDS}$ at $50^{\circ} \mathrm{C}$ for $2 \mathrm{~h}$ and exposed to $\mathrm{X}$-ray film at $-70^{\circ} \mathrm{C}$ in the presence of an intensifying screen.

Radioligand Binding Studies. For these studies, the HAtagged $\mathrm{H} 4$ receptor was transiently transfected into human embryonic kidney 293 cells into 100-mm plates using FUGENE-6 (Roche

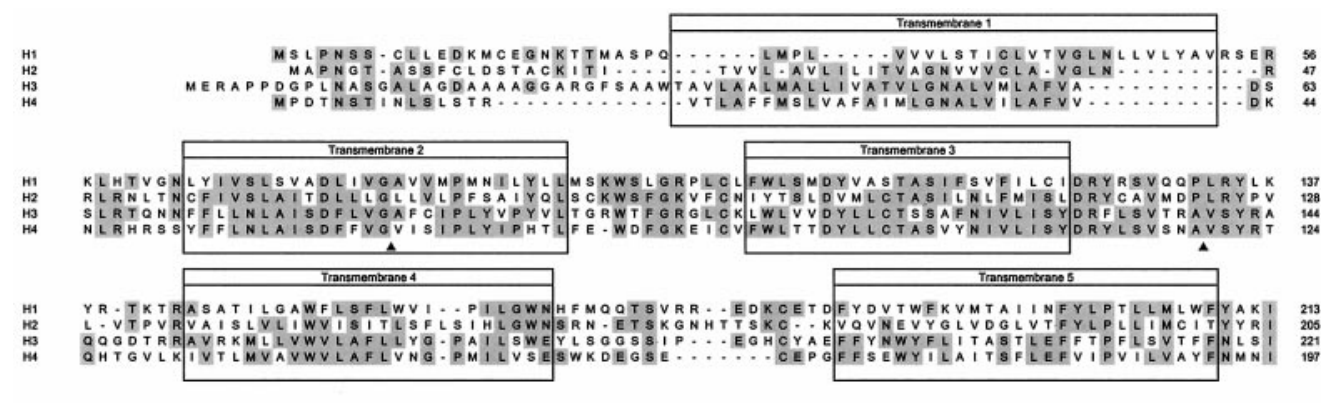

tamin tamine receptors $\mathrm{H} 1, \mathrm{H} 2, \mathrm{H} 3$ and $\mathrm{H} 4$. Residues identical among the receptors are shaded. Numeric amino acid positions are indicated on the right. The presence of introns interrupting the H4 sequence are shown as “ $\Delta$ ". H4 sequence data has been deposited in GenBank (accession number AY008280). 
Molecular Biochemicals, Rotkreuz, Switzerland) at a $6: 1$ ratio of FUGENE/DNA as detailed previously (Shapiro et al., 2000). At $72 \mathrm{~h}$ after transfection, cells were harvested and membranes prepared as described previously (Shapiro et al., 2000); membranes were stored as pellets at $-80^{\circ} \mathrm{C}$ until use. Radioligand binding assays were performed in a total volume of $500 \mu \mathrm{l}$ in $50 \mathrm{mM}$ Tris-Cl, $0.5 \mathrm{mM}$ EDTA, $\mathrm{pH} 7.4$, with $15 \mathrm{nM}\left[{ }^{3} \mathrm{H}\right]$ pyrilamine in the 96 -well format. After a 1-h incubation at room temperature, membranes were harvested by rapid filtration with a Brandel Harvester followed by two quick washes of ice-cold binding buffer. After drying, filters were placed into scintillation fluid and quantified by liquid scintillation spectrometry. Data were analyzed using GraphPad Prism (GraphPad Software, San Diego, CA) and data presented represents the mean \pm S.E.M. of computer-derived estimates of at least three separate experiments, each done in duplicate. For inhibition studies, 12 concentrations of unlabeled ligand spanning $6 \mathrm{log}$ units of test drug were used; for saturation studies, six concentrations of labeled ligand spanning 3 log units were used.

Immunoblot Analysis. The HA-tagged H4 receptor was transiently transfected into COS-7 monkey kidney cells (American Type Culture Collection, Manassas, VA) and membranes prepared from these cells as described previously (Lee et al., 2000). In brief, tissues were solubilized in sample buffer consisting of $50 \mathrm{mM}$ Tris-HCl, $\mathrm{pH}$ $6.5,1 \%$ SDS, $10 \%$ glycerol, $0.003 \%$ bromphenol blue, and $10 \% 2$-mercaptoethanol. The samples were subjected to polyacrylamide gel electrophoresis with $12 \%$ acrylamide gels and electroblotted onto nitrocellulose as described previously ( $\mathrm{Ng}$ et al., 1996). HA-tagged H4 immunoreactivity was revealed with the $3 \mathrm{~F} 10$ rat monoclonal antibody (Roche, Laval, Quebec).

Internalization Studies. For these studies, HA-tagged H4 receptors were transfected into HEK-293 cells as described above into $100-\mathrm{mm}$ plates. At $24 \mathrm{~h}$ after transfection, cells were split into 24-well plates containing poly-lysine-coated glass cover slips using
Dulbecco's modified Eagle's medium containing $10 \%$ dialyzed fetal calf serum. The medium was replaced $24 \mathrm{~h}$ later with serum-free Dulbecco's modified Eagle's medium. The next day, cells were exposed to $100 \mu \mathrm{M}$ histamine for $0,2,5$, or $15 \mathrm{~min}$ and then fixed with freshly prepared $4 \%$ paraformaldehyde in PBS for $30 \mathrm{~min}$ at room temperature. Cells were then permeabilized on ice $(0.2 \%$ Triton $\mathrm{X}-100$ in ice-cold PBS) for $20 \mathrm{~min}$ and then incubated with blocking buffer (5\% nonfat dry milk, $2 \%$ bovine serum albumin in PBS) for $1 \mathrm{~h}$ and then incubated with a 1:2000 dilution of monoclonal anti-HA antibody in blocking buffer overnight at $4^{\circ} \mathrm{C}$. The next day, after extensive washing in room temperature PBS, cells were incubated with secondary antibody (BODIPY-labeled goat anti-mouse; 1:250 dilution in blocking buffer) for $1 \mathrm{~h}$, washed extensively with PBS, and prepared for confocal microscopy as detailed previously (Berry et al., 1996; Kristiansen et al., 2000). Internalization was quantified as described previously (Berry et al., 1996; Willins et al., 1999).

\section{Results and Discussion}

As part of our ongoing search of novel genes encoding GPCRs, we queried the GenBank sequence databases maintained by NCBI with known GPCR sequences. A search with the histamine H3 receptor sequence retrieved partial sequences of a novel GPCR-encoding gene in an unfinished sequence of a human contig mapped to chromosome 18 (GenBank accession number AC007922). The retrieved sequence was obtained in three separate fragments, including one fragment that seemed to encode the receptor from the start methionine to TM2, another fragment encoding TM3, and a third fragment encoding TM5 through TM7 of a novel GPCRlike gene. These partial sequences were used to design primers for PCR amplification of human genomic DNA. Two frag-

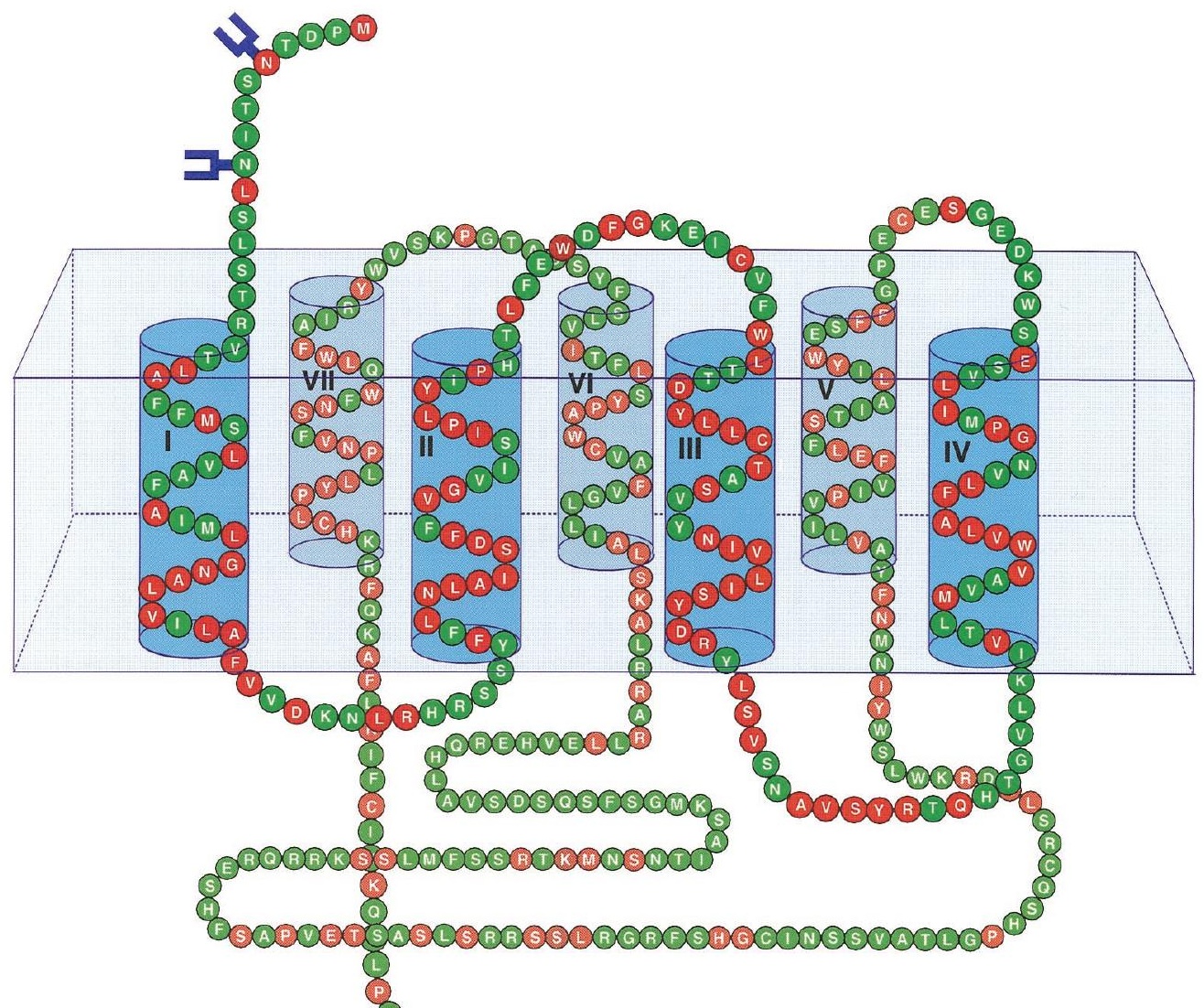

Fig. 2. Representative schematic of the human $\mathrm{H} 4$ receptor embedded in a cell membrane (box). Transmembrane regions are numbered and depicted with a top (extracellular)/bottom (intracellular) orientation. $N$-linked glycosylation sites are indicated in blue. Amino acids in red represent residues shared with the histamine receptor H3. 
ments of DNA, encoding the start methionine to TM2 and TM5 to TM6, respectively, were obtained and used as probes to screen a human genomic library. The Met-TM2 probe retrieved two phages encoding the $5^{\prime}$ end of the novel gene from the start methionine to TM2, whereas the TM5-TM6 probe retrieved four phages encoding the $3^{\prime}$ end of the gene from TM5 to the stop codon.

Using the TM5-TM6 probe, we screened several tissues by Northern analyses, which revealed a $3.0-\mathrm{kb}$ signal in rat testis. A human testis cDNA library was screened with both probes, which isolated two identical phages encoding the sequence from TM2 to TM6 of the gene. The sequences were identical in regions of overlap, confirming them to be partial sequences of the same gene. A comparison of the cDNA fragment to the GenBank genomic sequence revealed two introns interrupting the $\mathrm{H} 4$ receptor sequence. The first intron was $\sim 8 \mathrm{~kb}$ in length and located within the TM2-encoding region (interrupting the translated sequence "LNLAISDFFVG. . . VISIPLYIPH”). The second intron was downstream in the region encoding the second intracellular loop (interrupting the translated sequence "DRYLSVSNA... VSYRTQHTGV"). The length of this intron could not be determined, because the GenBank genomic sequence was incomplete.

A BLASTX search of the GenBank database with this novel DNA sequence revealed the greatest overall identity with the histamine receptor $\mathrm{H} 3(\sim 40 \%)$ and, more distantly, with other amine-type receptors of the GPCR family $(<30 \%)$. As also reported with the H3 receptor (Lovenberg et al., 1999), this novel receptor shared greater identity with other amine receptors including the serotonin, adrenergic, dopamine, and muscarinic receptors $(\sim 25 \%)$ than the histamine receptors $\mathrm{H} 1$ or $\mathrm{H} 2(\sim 20 \%)$. An alignment with the known histamine receptors (Fig. 1) revealed a higher sequence similarity to the $\mathrm{H} 3$ receptor (58\% in the TM regions) than to the $\mathrm{H} 1$ and $\mathrm{H} 2$ receptors (26 and $27 \%$ in the TM regions, respectively). It has been determined from their sequence similarities and phylogenetic analyses that the members of the histamine receptor family may have evolved from different ancestral genes and, through convergent evolution, acquired the residues to recognize and bind histamine (Leurs et al.,

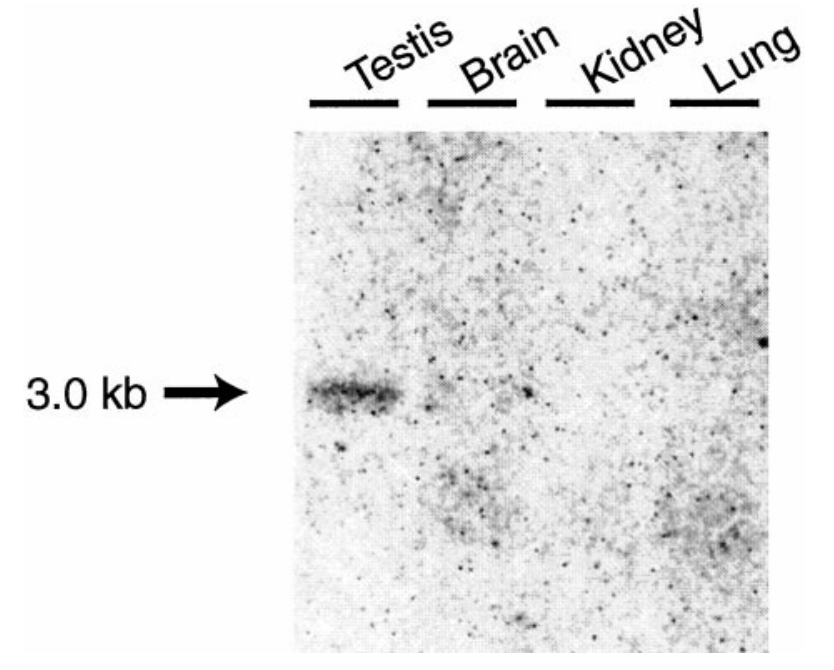

2000). This novel receptor, which we have named H4, seems to be a novel member of the histamine receptor subfamily, with closest relation to the $\mathrm{H} 3$ receptor. The amino acid sequence of the $\mathrm{H} 4$ receptor revealed many conserved residues and motifs found within the GPCR family (Fig. 2). Among these is an aspartic acid residue in TM 3 that is conserved in all cationic amine receptors and has been shown to be important in binding various amines to GPCRs (Savarese and Fraser, 1992). In addition, the human Met-TM2 probe was used to screen a rat genomic library, which retrieved a phage encoding the $5^{\prime}$ end of the novel gene from the start methionine to TM2. This fragment shared $71 \%$ identity (83\% in the TM regions) to the human $\mathrm{H} 4$ sequence, revealing a rat $\mathrm{H} 4$ ortholog.

The human Met-TM2 and TM5-TM6 probes were used in Northern analyses of various human and rat tissues. In the rat, the TM5-TM6 probe revealed a single transcript of $3 \mathrm{~kb}$

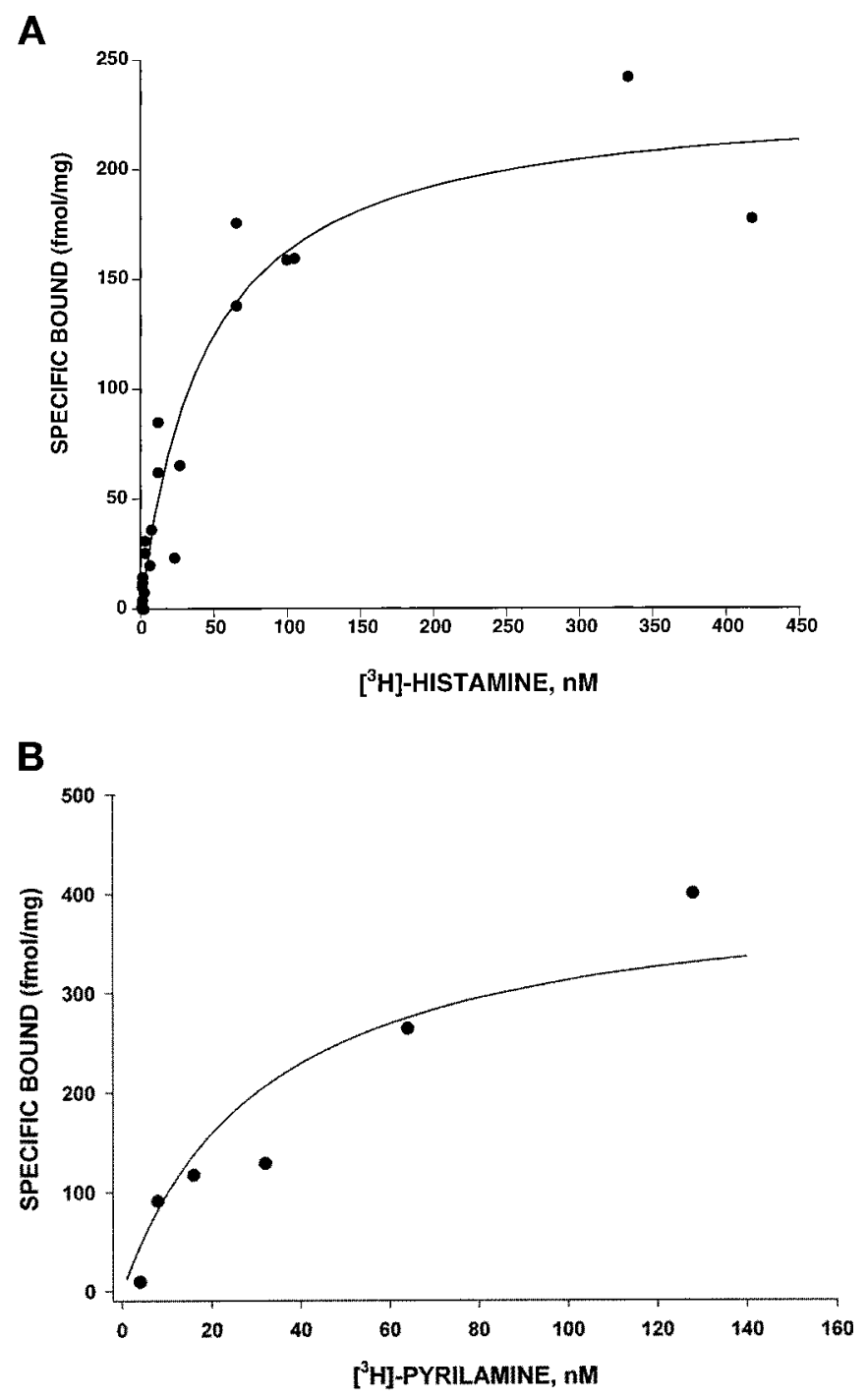

Fig. 4. Saturation binding studies of $\left[{ }^{3} \mathrm{H}\right]$ histamine $(\mathrm{A})$ and $\left[{ }^{3} \mathrm{H}\right]$ pyrilamine (B) specific binding in membranes prepared from HEK-293 cells transiently transfected with $\mathrm{H} 4 \mathrm{cDNA}$. Shown are typical results from experiment replicated three (A) and two times (B), with data representing mean of duplicate determinations. The curve represents the theoretical fit of the data A) $\left(K_{\mathrm{d}}=44 \mathrm{nM} ; B_{\max }=235 \mathrm{fmol} / \mathrm{mg}\right)$ and B) $\left(K_{\mathrm{d}}=32 \mathrm{nM}\right.$; 
in the testis (Fig. 3). The rat DNA fragment encoding from the start methionine to TM2 was used in Northern analyses of various rat tissues, revealing a $3-\mathrm{kb}$ transcript in intestine (data not shown). The $\mathrm{H} 3$ and $\mathrm{H} 4$ receptors had significantly different mRNA expression distributions. H4 mRNA was detected in two peripheral tissues (with no detectable levels in brain or various peripheral tissues, including heart, stomach, small intestine, kidney, or liver). In contrast, H3 mRNA has been reported to be abundant in the brain (Lovenberg et al., 1999). Thus, H4 is not likely to be the H3-subtype characterized previously in brain tissue (West et al., 1990; Leurs et al., 1996), which suggests that yet another histamine receptor subtype remains unidentified.

To test the $\mathrm{H} 4$ receptor for pharmacological characterization, we constructed a full-length open reading frame by individually amplifying and joining the three H4-encoding fragments by PCR. The receptor was expressed in HEK-293 cells, and a variety of tritiated ligands including $\left[{ }^{3} \mathrm{H}\right]$ hista-
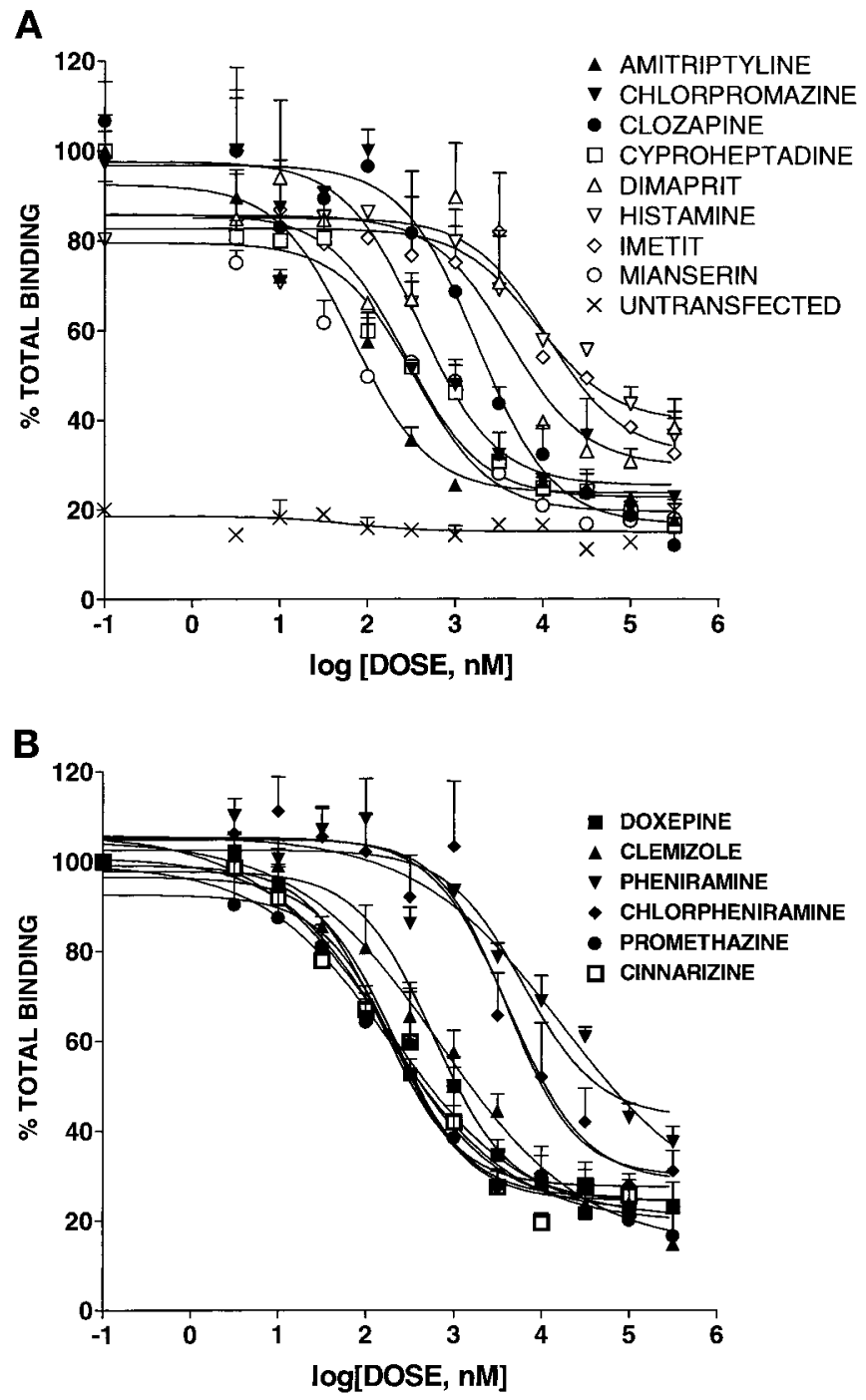

Fig. 5. Two sets (A and B) of competition binding of $\left[{ }^{3} \mathrm{H}\right]$ pyrilamine with various ligands in membranes prepared from HEK-293 cells transiently transfected with $\mathrm{H} 4 \mathrm{cDNA}$. Shown are typical results from competition binding experiments using $20 \mathrm{nM}\left[{ }^{3} \mathrm{H}\right]$ pyrilamine and various concentra- mine (histamine receptor nonselective), $\left[{ }^{3} \mathrm{H}\right]$ pyrilamine $(\mathrm{H} 1$ receptor-selective), and $\left[{ }^{3} \mathrm{H}\right]$ tiotidine ( $\mathrm{H} 2$ receptor-selective) were tested against unlabeled ligands including mianserin, cyproheptadine, histamine, and clozapine. Specific binding obtained with $\left[{ }^{3} \mathrm{H}\right]$ histamine $(44 \mathrm{nM})$ or $\left[{ }^{3} \mathrm{H}\right]$ pyrilamine $(5-20 \mathrm{nM})$ and mianserin $(100 \mu \mathrm{M})$ represented between 40 and $75 \%$ of total binding. Saturation binding studies performed with $\left[{ }^{3} \mathrm{H}\right]$ histamine and $\left[{ }^{3} \mathrm{H}\right]$ pyrilamine indicated respective $K_{\mathrm{d}}$ values of 44 and $32 \mathrm{nM}$ and respective $B_{\max }$ values of 235 and $437 \mathrm{fmol} / \mathrm{mg}$ of membrane protein (Fig. 4). No specific $\left[{ }^{3} \mathrm{H}\right]$ histamine or $\left[{ }^{3} \mathrm{H}\right]$ pyrilamine binding was observed with untransfected HEK-293 cells.

Competition binding studies with various selective and nonselective histaminergic compounds were demonstrated. Typical data are shown in Fig. 5 and summarized in Table 1. The highest affinities were for amitriptyline and chlorpromazine, which are tricyclic compounds that have high affinity for the $\mathrm{H} 1$ histamine receptor (see on-line database at: http: / / pdsp.cwru.edu/pdsp.asp). Doxepin, cinnarizine, and promethazine (H1-selective antagonists) also displayed high affinity for the $\mathrm{H} 4$ receptor. Imetit (H3-selective agonist) and dimaprit (H2-selective agonist) had weak affinities for the H4 receptor, whereas mianserin (an $\mathrm{H} 1$ and $\mathrm{H} 2$ antagonist), cyproheptadine (a nonselective histamine/serotonin antagonist), and clozapine (an atypical antipsychotic drug with high affinity for a large number of receptors) had moderate affinities. The pharmacological profile of the $\mathrm{H} 4$ receptor is distinct from the histamine receptors (Table 1).

An HA epitope tag-encoding sequence was inserted after the start methionine for Western blot visualization. This plasmid was transiently transfected into COS-7 cells. Immunoblot analyses of membranes from these cells revealed high expression of the $\mathrm{H} 4$ receptor (Fig. 6A), with bands at $44 \mathrm{kDa}$, $85 \mathrm{kDa}$, and higher molecular mass species. The $44-\mathrm{kDa}$ band matched the expected mass of the unglycosylated receptor and the $85-\mathrm{kDa}$ band matched the glycosylated form. The bands $>250 \mathrm{kDa}$ represent oligomeric receptor species (Lee et al., 2000). The functional activity of the HA-tagged H4 receptor was examined by measuring histamine-induced internalization. As shown in Fig. 6B, exposure to $100 \mu \mathrm{M}$

TABLE 1

Ligand affinities for the $\mathrm{H} 4$ receptor

Data represent mean \pm S.E. for two to four separate experiments. Twelve different concentrations spanning $6 \mathrm{log}$ units of test drug were used to displace $15 \mathrm{nM}$ $\left[{ }^{3} \mathrm{H}\right]$ pyrilamine.

\begin{tabular}{lcc}
\hline & \multicolumn{1}{c}{$-\operatorname{LogEC} C_{50}\left(K_{\mathrm{i}}\right)$} & Hill Coefficient \\
\hline & $n M$ & \\
Amitriptyline & $7.31 \pm 0.26(33.6)$ & 0.8 \\
Chlorpromazine & $7.13 \pm 0.29(50.2)$ & 0.7 \\
Doxepin & $6.79 \pm 0.13(105.9)$ & 0.6 \\
Cinnarizine & $6.73 \pm 0.20(141.6)$ & 0.7 \\
Promethazine & $6.71 \pm 0.19(150.2)$ & 0.6 \\
Cyproheptadine & $6.53 \pm 0.09(201.5)$ & 0.9 \\
Clemizole & $6.16 \pm 0.12(402.2)$ & 0.5 \\
Mianserin & $5.96 \pm 0.40(750.0)$ & 0.9 \\
Clozapine & $5.90 \pm 0.22(849.6)$ & 1.2 \\
Chlorpheniramine & $5.39 \pm 0.16(2910.0)$ & 1.1 \\
Histamine & $5.30 \pm 0.04(3442.3)$ & 0.5 \\
Imetit & $5.25 \pm 0.44(3795.6)$ & 0.2 \\
Pheniramine & $5.21 \pm 0.47(4184.0)$ & 0.2 \\
Dimaprit & $4.76 \pm 0.19(11812.7)$ & 0.4 \\
$\alpha$-Methylhistamine & $>10,000$ & Undetermined
\end{tabular}


histamine caused an internalization of $\mathrm{H} 4$ receptors from the plasma membrane to intracellular sites. Quantification revealed a rapid internalization of $\mathrm{H} 4$ receptors with significant internalization at 2 min after agonist exposure (Fig. 6C). These results indicated that the surface expression of the $\mathrm{H} 4$ receptor is functionally regulated by histamine exposure in a time-dependent fashion.

During the preparation of this article, other researchers (Oda et al., 2000) also reported the identification of a cDNA encoding a novel histamine receptor. This cDNA sequence varied from our sequence at three nucleotide positions, which translated into differences in three amino acids. Specifically, Ala138, His206, and Gln253 (as found in our sequence) were replaced by valine and two arginines, respectively. In the study by Oda et al., expression analyses revealed signals in peripheral blood leukocytes, small intestine, spleen and colon, and no expression in the brain. In addition, they reported histamine signaling through the novel receptor to be pertus- sis toxin-sensitive, suggesting a $\mathrm{G}_{\mathrm{i} / \mathrm{o}}$ pathway of activation. For our receptor, we examined several second messengereffector systems. We were not able to demonstrate $\mathrm{H} 4$ receptor-mediated inhibition of forskolin-stimulated adenylyl cyclase, alterations in phosphoinositide hydrolysis, or mitogenactivated protein kinase phosphorylation (extracellular signal-regulated kinase 1/2 phosphorylation) in HEK-293 cells.

In conclusion, we report the discovery of a novel histamine receptor, H4. Previously, it was observed that histamine receptors shared greater sequence similarities with other biogenic amine-binding GPCRs than with one another. H4 shared highest sequence similarity with the previously reported histamine $\mathrm{H} 3$ receptor. In combination with the $\mathrm{H} 1$, $\mathrm{H} 2$, and $\mathrm{H} 3$ receptors, this receptor, with its unique distribution and pharmacology, will undoubtedly provide further insight into the physiological functions and therapeutic applications of this receptor family.

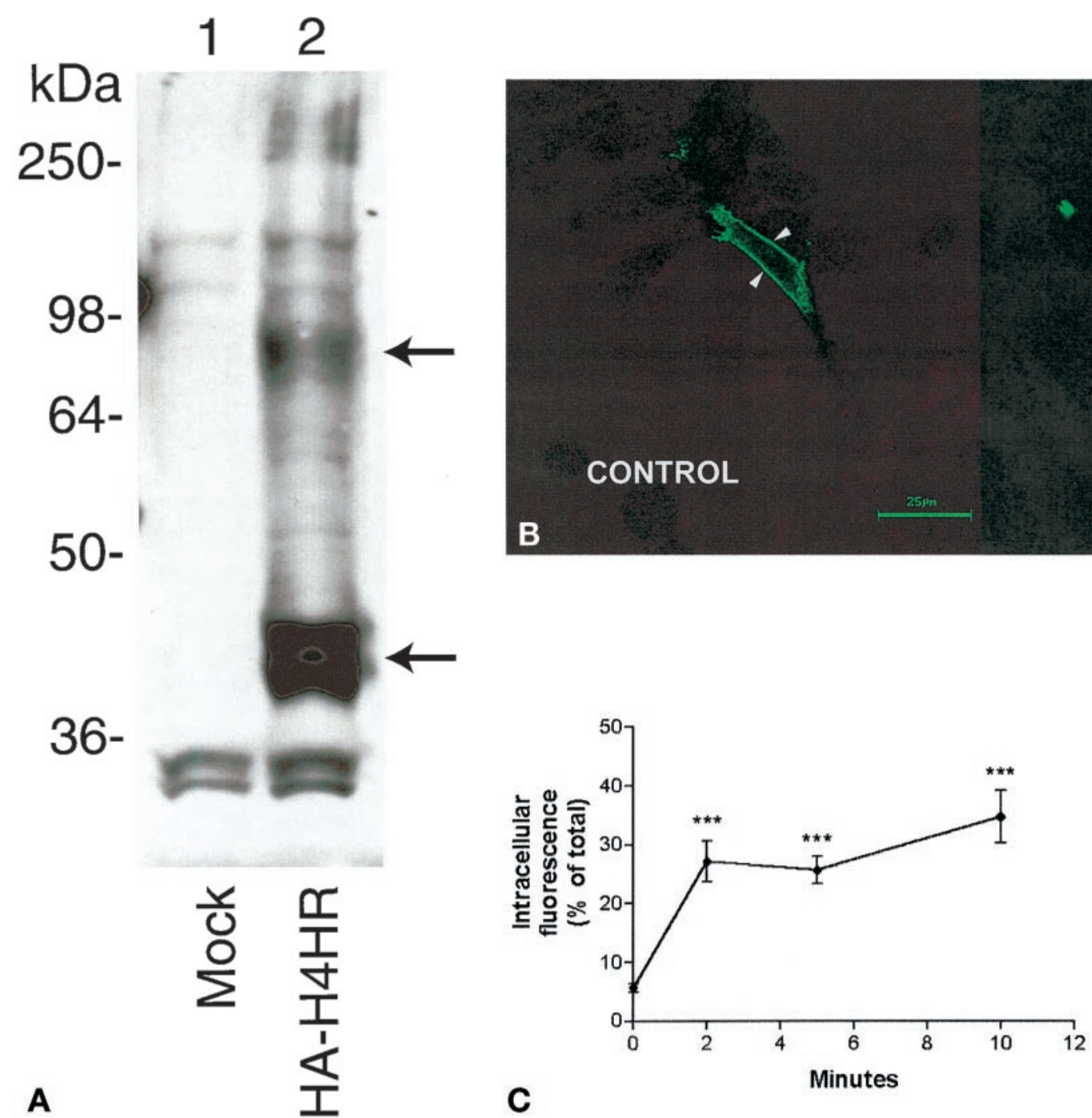

Fig. 6. A, immunoblot analysis of membranes from mock-transfected COS-7 cells (lane 1) and COS-7 cells expressing the HA-H4 receptor (lane 2). Membrane protein $(25 \mu \mathrm{g})$ was used in each lane. Arrows indicate the unglycosylated (bottom) and glycosylated (top) receptor. B) histamine-induced internalization of the $\mathrm{H} 4$ receptor in HEK-293 cells. Shown are representative confocal micrographs in which HA-tagged H4 receptors were examined in cells exposed to vehicle (PBS) or $100 \mu \mathrm{M}$ histamine for $5 \mathrm{~min}$ and then prepared for microscopy as described previously (Berry et al., 1996; Willins et al., 1999; Kristiansen et al., 2000). Arrowheads and arrows indicate cell-surface and internalized receptors, respectively. C, histamine-induced time-dependent internalization of the H4 receptor in HEK-293 cells. Shown are the mean \pm S.E.M. of the percentage internalization of HA-tagged H4 


\section{References}

Berry SA, Shah MC, Khan N and Roth BL (1996) Rapid agonist-induced internalization of the 5-hydroxytryptamine2A receptor occurs via the endosome pathway in vitro. Mol Pharmacol 50:306-313.

Gantz I, Schaffer M, DelValle J, Logsdon C, Campbell V, Uhler M and Yamada T (1991) Molecular cloning of a gene encoding the histamine H2 receptor. Proc Natl Acad Sci USA 88:429-433.

Heise CE, O'Dowd BF, Figueroa DJ, Sawyer N, Nguyen T, Im DS, Stocco R, Bellefeuille JN, Abramovitz M, Cheng R, et al. (2000) Characterization of the human cysteinyl leukotriene 2 receptor. J Biol Chem 275:30531-30536.

Hill SJ, Ganellin CR, Timmerman H, Schwartz JC, Shankley NP, Young JM, Schunack W, Levi R and Haas HL (1997) International Union of Pharmacology. XIII. Classification of histamine receptors. Pharmacol Rev 49:253-278.

Kolakowski LF Jr, O'Neill GP, Howard AD, Broussard SR, Sullivan KA, Feighner SD, Sawzdargo M, Nguyen T, Kargman S, Shiao LL, et al. (1998) Molecular characterization and expression of cloned human galanin receptors GALR2 and GALR3. J Neurochem 71:2239-2251.

Kristiansen K, Kroeze WK, Willins DL, Gelber EI, Savage JE, Glennon RA and Roth BL (2000) A highly conserved aspartic acid (Asp-155) anchors the terminal amine moiety of tryptamines and is involved in membrane targeting of the 5-HT(2A) serotonin receptor but does not participate in activation via a "salt-bridge disruption mechanism. J Pharmacol Exp Ther 293:735-746.

Lee DK, George SR, Evans JF, Lynch KR and O'Dowd BF (2001) Orphan G proteincoupled receptors in the CNS. Curr Opin Pharmacol, in press.

Lee SP, O'Dowd BF, Ng GY, Varghese G, Akil H, Mansour A, Nguyen T and George SR (2000) Inhibition of cell surface expression by mutant receptors demonstrates that D2 dopamine receptors exist as oligomers in the cell. Mol Pharmacol 58:120 128.

Leurs R, Hoffmann M, Wieland K and Timmerman H (2000) H3 receptor gene is cloned at last. Trends Pharmacol Sci 21:11-12.

Leurs R, Kathmann M, Vollinga RC, Menge WM, Schlicker E and Timmerman H (1996) Histamine homologues discriminating between two functional H3 receptor assays. Evidence for H3 receptor heterogeneity? J Pharmacol Exp Ther 276:1009_ 1015.

Lovenberg TW, Roland BL, Wilson SJ, Jiang X, Pyati J, Huvar A, Jackson MR and Erlander MG (1999) Cloning and functional expression of the human histamine H3 receptor. Mol Pharmacol 55:1101-1107.

Marchese A, Docherty JM, Nguyen T, Heiber M, Cheng R, Heng HH, Tsui LC, Shi X, George SR and O'Dowd BF (1994) Cloning of human genes encoding novel G protein-coupled receptors. Genomics 23:609-618.
Marchese A, George SR, Kolakowski LF Jr, Lynch KR and O’Dowd BF (1999) Novel GPCRs and their endogenous ligands: Expanding the boundaries of physiology and pharmacology. Trends Pharmacol Sci 20:370-375.

Ng GY, O’Dowd BF, Lee SP, Chung HT, Brann MR, Seeman P and George SR (1996) Dopamine D2 receptor dimers and receptor-blocking peptides. Biochem Biophys Res Commun 227:200-204.

Nguyen T, Erb L, Weisman GA, Marchese A, Heng HH, Garrad RC, George SR, Turner JT and O'Dowd BF (1995) Cloning, expression, and chromosomal localization of the human uridine nucleotide receptor gene. J Biol Chem 270:30845-30848. Oda T, Morikawa N, Saito Y, Masuho Y and Matsumoto SI (2000) Molecular cloning and characterization of novel type of histamine receptor preferentially expressed in leukocytes. J Biol Chem 275:36781-36786.

O'Dowd BF, Lee DK, Huang W, Nguyen T, Cheng R, Liu Y, Wang B, Gershengorn MC and George SR (2000) TRH-R2 exhibits similar binding and acute signaling but distinct regulation and anatomic distribution compared with TRH-R1. Mol Endocrinol 14:183-193.

Retief JD, Lynch KR and Pearson WR (1999) Panning for genes-A visual strategy for identifying novel gene orthologs and paralogs. Genome Res 9:373-382.

Savarese TM and Fraser CM (1992) In vitro mutagenesis and the search for structure-function relationships among G protein-coupled receptors. Biochem J 283:119.

Shapiro DA, Kristiansen K, Kroeze WK and Roth BL (2000) Differential modes of agonist binding to 5 -hydroxytryptamine ${ }_{2 \mathrm{~A}}$ serotonin receptors revealed by mutation and molecular modeling of conserved residues in transmembrane region 5 . Mol Pharmacol 58:877-886.

West RE Jr, Zweig A, Shih NY, Siegel MI, Egan RW and Clark MA (1990) Identification of two H3-histamine receptor subtypes. Mol Pharmacol 38:610-613.

Willins DL, Berry SA, Alsayegh L, Backstrom JR, Sanders-Bush E, Friedman L and Roth BL (1999) Clozapine and other 5-hydroxytryptamine-2A receptor antagonists alter the subcellular distribution of 5-hydroxytryptamine-2A receptors in vitro and in vivo. Neuroscience 91:599-606.

Yamashita M, Fukui H, Sugama K, Horio Y, Ito S, Mizuguchi H and Wada H (1991) Expression cloning of a cDNA encoding the bovine histamine $\mathrm{H} 1$ receptor. Proc Natl Acad Sci USA 88:11515-11519.

Send reprint requests to: Dr. Brian F. O'Dowd, Department of Pharmacology, University of Toronto, Medical Science Building, 8 Taddle Creek Rd. Rm 4353, Toronto, Ontario, Canada M5S 1A8. E-mail: brian.odowd@utoronto.ca 